\title{
Glucagon Response to Hypoglycemia in Sympathectomized Man
}

\author{
Jerry P. Palmer, David P. Henry, James W. Benson, \\ David G. Johnson, and John W. EnsincK \\ From the Department of Medicine, University of Washington, School of \\ Medicine, Seattle, Washington 98195
}

A B S T R A C T Hypoglycemia stimulates immunoreactive glucagon (IRG) secretion and increases the activity of the sympathetic nervous system. To ascertain if the augmented alpha cell activity evoked by glucopenia is mediated by the adrenergic nervous system, the glucagon response to insulin-induced hypoglycemia of five subjects with neurologically complete cervical transections resulting from trauma, thereby disrupting their hypothalamic sympathetic outflow, was compared to six healthy volunteers. In addition to clinical neurological evaluation, completeness of sympathectomy was verified by failure to raise plasma norepinephrine levels during hypoglycemia compared to the two- to threefold increase observed in controls. Total IRG response (IRG area above basal 0-90 $\mathrm{min}$ ) and peak IRG levels achieved were the same in the quadriplegics and the controls. Although the glucagon rise tended to be slower, and the peak levels attained occurred later in the quadriplegic patients than in the controls, this response was appropriate for their sugar decline, which was slower and reached the nadir later than in the control subjects.

These observations that the glucagon release during insulin-induced hypoglycemia is normal in subjects whose hypothalamic sympathetic outflow has been interrupted provide strong evidence that the sympathetic nervous system does not mediate the glucagon response to hypoglycemia.

\section{INTRODUCTION}

In addition to the control of insulin and glucagon secretion by circulating levels of substrates such as amino

This work was presented in part at the 34th Annual Meeting of the American Diabetes Association, Atlanta, Ga., 1974.

Dr. Palmer was the recipient of a National Institutes of Health Research Fellowship (1F22 AMO 1342-01) while conducting this research. Dr. Henry's present address is Eli Lilly Laboratory, Marion County General Hospital, Indianapolis, Ind. 46202.

Received for publication 8 August 1975 and in revised form 29 October 1975. acids, glucose, and free fatty acids, it has been suggested that the sympathetic nervous system, through direct neural innervation of the alpha and beta cells and/or via circulating catecholamines, also modulates the release of these hormones. Stimulation and suppression of insulin and glucagon levels in several species, including man, with administration of adrenergic agonists and antagonists have been reported (1-7). The physiological significance of these observations is uncertain, since in sympathectomized man basal- and glucose-stimulated insulin levels are normal (8). We have previously reported normal glucagon responses to hypoglycemia in man during the administration of phentolamine and propranolol (9). Although we used standard doses of propranolol and phentolamine and elicited characteristic cardiovascular blockade, we questioned whether the dosage might be insufficient to block the sympathetic innervation of the alpha cell. Therefore, in this paper we describe the glucagon responses to hypoglycemia in quadriplegic patients in whom a cervical cord lesion has physically interrupted the augmented hypothalamicsympathetic activity that normally results from glucopenia.

\section{METHODS}

Subjects. Seven healthy, nonobese, male volunteers, 20 35-yr-old, served as controls in evaluating the normal immunoreactive glucagon (IRG) ${ }^{1}$ response to hypoglycemia. The five quadriplegic patients (four males, one female) were nonobese, between $16-31-\mathrm{yr}$ of age and were healthy except for their neurological impairment. A neurologically complete cervical cord transection (motor and sensory) in each patient had resulted from trauma. The seven controls for the norepinephrine response to hypoglycemia included two subjects from the IRG control group plus an additional five (four males, one female) healthy subjects between 24-52 yr of age. All subjects had a negative family history of diabetes.

Protocol. Tests began between 8-9 a.m. after an overnight fast without antecedent dietary preparation. All subjects were informed of the nature, purpose, and potential risks before their voluntary participation. Four base-line

${ }^{1}$ Abbreviation used in this paper: IRG, immunoreactive glucagon. 
samples were obtained over a 1-h control period and then regular insulin was administered intravenously over 5-10 s. Control subjects received $0.15 \mathrm{U} / \mathrm{kg}$ except for one subject who did not tolerate this dose and was therefore repeated at $0.1 \mathrm{U} / \mathrm{kg}$. The quadriplegic patients required $0.2 \mathrm{U} / \mathrm{kg}$ to induce a similar degree of hypoglycemia. Blood was drawn every $5 \mathrm{~min}$ for $50 \mathrm{~min}$, then at 60,75 , and $90 \mathrm{~min}$ after the insulin injection.

Determinations. Glucose was measured by an autoanalyzer adaptation of the Hoffman ferricyanide technique (10). In our IRG assay we extract each sample with acetone, use benzamidine at a final concentration of $0.01 \mathrm{M}$, employ antiserum $30 \mathrm{~K}$, and separate bound-from-free antibody by cellulose adsorption. Details of this assay have been published (9). Norepinephrine was measured by a sensitive radio enzymatic method (11). Conventional stastistical analyses and IRG areas were calculated on a Wang model 600 computer (Wang Laboratories, Inc., Tewksbury, Mass.). Basal values are expressed as the mean of the four base-line values obtained for each patient.

\section{RESULTS}

Fig. 1 depicts the plasma norepinephrine response to insulin-induced hypoglycemia in both control and cordlesioned patients. In the controls, the mean glucose nadir was observed at $30 \mathrm{~min}$ and the mean plasma norepinephrine more than doubled to a peak value at $40 \mathrm{~min}$. Basal plasma norepinephrine levels in the cord-lesioned
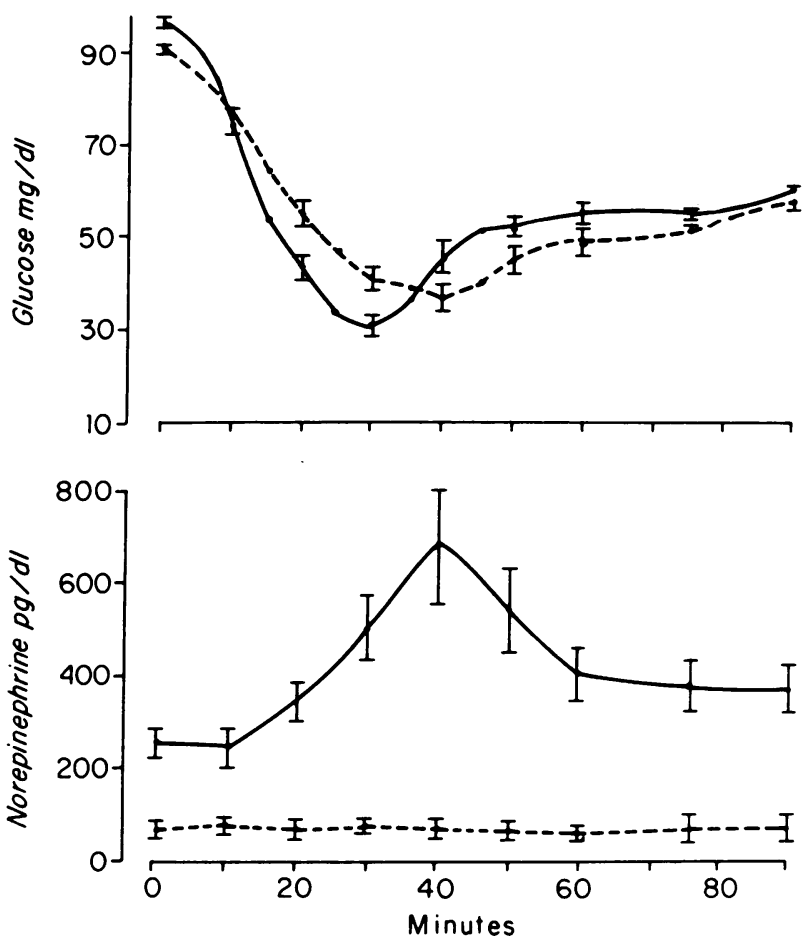

Figure 1 Plasma glucose and norepinephrine responses, mean $\pm S E M$, to intravenous insulin $(0.1-0.2 \mathrm{U} / \mathrm{kg})$ given at 0 time in five quadriplegic patients (-- -) and seven controls (-).

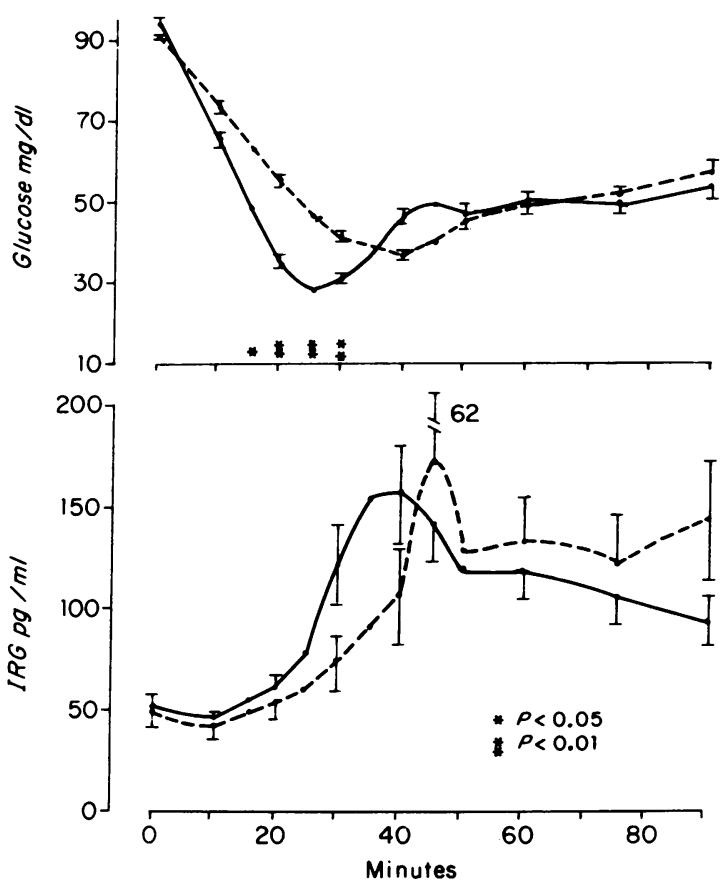

FIGURE 2 Plasma glucose and IRG responses, mean \pm SEM, to intravenous insulin $(0.1-0.2 \mathrm{U} / \mathrm{kg})$ given at 0 time in five quadriplegic patients (---) and six controls (-). The SEM of the IRG of the quadriplegic patients at 45 $\min$ was $62 \mathrm{pg} / \mathrm{ml}$.

patients were one-third to one-fourth the levels in the controls, and although the quadriplegic patients achieved a similar degree of hypoglycemia, there was no rise in mean or individual plasma norepinephrine levels.

The IRG and glucose responses in the quadriplegics and the normal volunteers are shown in Fig. 2. Although the control subjects used for evaluating the norepinephrine and those for the IRG response to hypoglycemia were not all the same volunteers, no statistical differences in the glucose changes were observed between the two control groups. The quadriplegic patients displayed relative insulin resistance, probably related to their inactivity (12). Even with slightly larger doses of insulin, the glucose fall in the sympathectomized patients was slower and reached the nadir later than in the controls. In addition, the mean maximal degree of hypoglycemia was slightly greater in the controls $(29 \mathrm{mg} / \mathrm{dl}$ ) than in the quadriplegics ( $37 \mathrm{mg} / \mathrm{dl}$ ). The IRG responses of both groups were not statistically different $(P<0.05)$ at any point, although there was a tendency for the IRG rise and peak to be delayed in the quadriplegics which coincided with their slower glucose fall. In controls, and in cord-transected patients, the mean peak IRG levels, 158 and $173 \mathrm{pg} / \mathrm{ml}$, were statistically indistinguishable. In addition, when the total IRG re- 
sponse to the insulin-induced hypoglycemia was expressed as the IRG area above basal for the $90 \mathrm{~min}$ of the study, the mean area \pm SEM in the normals of $4,565 \pm 744 \mathrm{pg} / \mathrm{ml}$ per $90 \mathrm{~min}$ was not different from that in the quadriplegics, $4,819 \pm 1,322 \mathrm{pg} / \mathrm{ml}$ per 90 $\min$.

\section{DISCUSSION}

A variety of experimental approaches using adrenergic agonists and antagonists (3-7) and neural stimulation $(13,14)$ have strongly suggested that the sympathoadrenal system may modulate glucagon secretion. In addition, many states characterized by catecholamine excess are associated with hyperglucagonemia (9, 1520) ; nevertheless, a cause-effect relationship between sympathetic nervous system discharge or epinephrine release from the adrenal, and stimulation of glucagon secretion, especially in man, has not been identified. During hypoglycemia there is stimulation of glucagon secretion (9), increased sympathetic neural outflow, and increased adrenal medullary secretion with resultant increases in plasma and urinary epinephrine and norepinephrine levels $(21,22)$. We have induced hypoglycemia in sympathectomized man to determine the importance of the sympatho-adrenal system in the glucagon response.

In each of our five quadriplegic patients, the absence of any sensory or motor function below the levels of their cord lesion, the failure of norepinephrine levels to rise above the base line throughout the study, plus the absence of sweating or an increase in systolic blood pressure during the induced hypoglycemia, provide strong evidence that their hypothalamic sympathetic outflow was completely interrupted. Since quadriplegic patients receiving 2 -deoxyglucose to induce glucopenia have no total catecholamine response (23), and urinary epinephrine does not rise during glucopenia in surgically sympathectomized patients (24), it is very likely that insulin-induced hypoglycemia in our cordtransected patients did not result in adrenal medullary discharge.

Christensen and Iversen have reported the release of large amounts of norepinephrine from the dog pancreas during perfusion with medium containing no glucose; but in the one experiment where they compared perfusion mediums with glucose concentrations of 150 and $25 \mathrm{mg} / \mathrm{dl}$, no difference in norepinephrine release was seen (25). Since the nadir of plasma glucose in our control and quadriplegic subjects was 29 and $37 \mathrm{mg} / \mathrm{dl}$ respectively, it is unlikely that local release of norepinephrine in the pancreas occurred and influenced IRG secretion.

The peak and the total IRG responses in our sympathectomized patients were not distinguishable from the response in the controls and, in fact, tended to be slightly greater. Since the alpha cell can respond almost immediately to stimulation as demonstrated in man using arginine $(26,27)$ and in experimental animals employing many stimuli including hypoglycemia (4), any tendency toward a delay in IRG response in our quadriplegic patients can be adequately accounted for by the slower fall in glucose in these patients.

The normal IRG response to hypoglycemia in sympathectomized man that we observed, plus the observation that alpha cells in tissue culture, where neural control must be absent, are stimulated by low glucose concentrations (28), allows us to conclude that the glucagon response to hypoglycemia is not mediated by the sympathetic nervous system, and is very likely a direct response of the alpha cell to glucopenia. On the basis of our data we cannot exclude the possibility that during hypoglycemia in normal man there is alpha cell stimulation by increased sympathetic neural activity, but the IRG levels in our quadriplegic subjects are strong evidence that this potential neural modulation is not required for a normal IRG response. Whether or not the sympathetic nervous system modulates glucagon secretion under other circumstances remains unknown.

\section{ACKNOWLEDGMENTS}

The authors are grateful to Ms. Claudine Nist, Ms. Ellen Laschansky, and Ms. Martha Knoeber for their excellent technical assistance, to Ms. Pat Johnson for typing the manuscript, and to Dr. Walter Stolov for referring his patients.

A portion of this work was conducted through the Clinical Research Center of the University of Washington supported by National Institutes of Health grant RR-37. This investigation was supported in part by U. S. Public Health Service grants AM-16007, AM-13457, Program Project grant HD-04872, Department of Health, Education, and Welfare-Rehabilitation Services Administration grants 16P56818, 13-P-58611, and by National Institutes of Health grant AN-17047.

\section{REFERENCES}

1. Porte, D., Jr. 1967. Beta adrenergic stimulation of insulin release in man. Diabetes. 16: 150-155.

2. Porte, D., Jr., A. L. Graber, T. Kuzuya, and R. H. Williams. 1966. The effect of epinephrine on immunoreactive insulin levels in man. J. Clin. Invest. 45: 228236.

3. Iversen, J. 1973. Adrenergic receptors and the secretion of glucagon and insulin from the isolated, perfused canine pancreas. J. Clin. Invest. 52: 2102-2116.

4. Weir, G. C., S. D. Knowlton, and D. B. Martin. 1974. Glucagon secretion from the perfused rat pancreas. Studies with glucose and catecholamines. J. Clin. Invest. 54: 1403-1412.

5. Luyckx, A. S., and P. J. Lefebvre. 1974. Mechanisms involved in the exercise-induced increase in glucagon secretion in rats. Diabetes. 23: 81-93.

6. Gerich, J. E., J. H. Karam, and P. H. Forsham. 1973. Stimulation of glucagon secretion by epinephrine in man. J. Clin. Endocrinol. Metab. 37: 479-481. 
7. Gerich, J. E., M. Langlois, C. Noacco, V. Schneider, and P. H. Forsham. 1974. Adrenergic modulation of pancreatic glucagon secretion in man. J. Clin. Invest. 5.3: 1441-1446.

8. Brodows, R. G., F. X. Pi-Sunyer, and R. G. Campbell. 1974. Insulin secretion in adrenergic insufficiency in man. J. Clin. Endocrinol. Metab. 38: 1103-1108.

9. Walter, R. M., R. J. Dudl, J. P. Palmer, and J. W. Ensinck. 1974. The effect of adrenergic blockade on the glucagon responses to starvation and hypoglycemia in man. J. Clin. Invest. 54: 1214-1220.

10. Hoffman, W. S. 1937. A rapid photoelectric method for the determination of glucose in blood and urine. J. Biol. Chem. 120: 51-55.

11. Henry, D. P., B. J. Starman, D. G. Johnson, and R. $H$. Williams. 1975. A sensitive radioenzymatic assay for norepinephrine in tissues and plasma. Life Sci. 16: 375384.

12. Lipman, R. L., J. J. Schnure, E. M. Bradley, and F. R. Lecocq. 1970. Impairment of peripheral glucose utilization in normal subjects by prolonged bed rest. J. Lab. Clin. Med. 76: 221-230.

13. Marliss, E. B., L. Girardier, J. Seydoux, C. B. Wollheim, Y. Kanazawa, L. Orci, A. E. Renold, and D. Porte, Jr. 1973. Glucagon release induced by pancreatic nerve stimulation in the dog. J. Clin. Invest. 52: 12461259.

14. Frohman, L. A., and L. L. Bernardis. 1971. Effect of hypothalamic stimulation on plasma glucose, insulin, and glucagon levels. Am. J. Physiol. 221: 1596-1603.

15. Müller, W. A., G. R. Faloona, and R. H. Unger. 1973. Hyperglucagonemia in diabetic ketoacidosis. Its prevalence and significance. Am. J. Med. 54: 52-57.

16. Lindsey, C. A., G. R. Faloona, and R. H. Unger. 1974. Plasma glucagon in nonketotic hyperosmolar coma. $J A M A$ (J. Am. Med. Assoc.). 229: 1771-1773.

17. Felig, P., J. Wahren, R. Hendler, and G. Ahlborg. 1972. Plasma glucagon levels in exercising man. $N$. Engl. J. Med. 287: 184-185.

18. Lindsey, A., F. Santeusanio, J. Braaten, G. R. Faloona, and R. H. Unger. 1974. Pancreatic alpha-cell function in trauma. JAMA (J. Am. Med. Assoc.). 227: 757761.

19. Rocha, D. M., F. Santeusanio, G. R. Faloona, and R. H. Unger. 1973. Abnormal pancreatic alpha-cell function in bacterial infections. N. Engl. J. Med. 288: 700-703.

20. Willerson, J. T., D. R. Hutcheson, S. J. Leshin, G. R. Faloona, and R. H. Unger. 1974. Serum glucagon and insulin levels and their relationship to blood glucose values in patients with acute myocardial infarction and acute coronary insufficiency. Am. J. Med. 57: 747-753.

21. Luft, R., E. Cerasi, L. L. Madison, U. S. von Euler, L. D. Casa, and A. Roovete. 1966. Effect of a small decrease in blood-glucose on plasma-growth-hormone and urinary excretion of catecholamines in man. Lancet. II : 254-256.

22. Christensen, N. J. 1974. Plasma norepinephrine and epinephrine in untreated diabetics, during fasting and after insulin administration. Diabetes. 23: 1-8.

23. Brodows, R. G., F. X. Pi-Sunyer, and R. G. Campbell. 1973. Neural control of counter-regulatory events during glucopenia in man. J. Clin. Invest. 52: 1841-1844.

24. French, E. B., and R. Kilpatrick. 1955. The role of adrenaline in hypoglycaemic reactions in man. Clin. Sci. (Oxf.). 14: 639-651.

25. Christensen, N. J., and J. Iversen. 1973. Release of large amounts of noradrenaline from the isolated perfused canine pancreas during glucose deprivation. Diabetologia. 9 : 396-399.

26. Palmer, J. P., R. M. Walter, and J. W. Ensinck. 1975. Arginine-stimulated acute phase of insulin and and glucagon secretion. I. In normal man. Diabetes. 24: 735740 .

27. Blackard, W. G., N. C. Nelson, and S. S. Andrews. 1974. Portal and peripheral vein immunoreactive glucagon concentrations after arginine or glucose infusions. Diabetes. 23 : 199-202.

28. Marliss, E. B., C. B. Wollheim, B. Blondel, L. Orci, A. E. Lambert, W. Stauffacher, A. A. Like, and A. E. Renold. 1973. Insulin and glucagon release from monolayer cell cultures of pancreas from newborn rats. Eur. J. Clin. Invest. 3 : 16-26. 